Quebec Cooperative Study

of Friedreich's Ataxia

\title{
Friedreich's Ataxia in Northern Italy II. Biochemical Studies in Cultured Cells
}

\author{
B. BERTAGNOlio, G. UZIEl, E. BOTTACHI, G. CRENNA, A. D'ANGElo, S. DI DONATO
}

SUMMARY: Pyruvate and palmitate oxidations by' cultured fibroblasts suspensions were measured in optimized conditions and proved to be within normal range in the cells from Friedreich's patients. However, when pyruvate oxidation was measured by direct assay of the pyruvate dehydrogenase complex, this enzyme activity proved to be significantly lower in Friedreich's than in controls' cells. These

RÉSUMÉ: Nous avons mesuré dans des conditions optimales l'oxidation par des suspensions de fibroblastes en culture du puruvate et du palmitate. Celles-ci s'avérèrent normales dans les cellules de patients souffrant d'ataxie de Friedreich. Cependant lorsque loxidation du pyruvate fut mesurée par un dosage direct du complexe de la pyruvate dehydrogenase, l'activité de cet enz.'me s'avéra significativement diminuée chez les Friedreich par rapport aux abnormalities were not observed when the cells were sonicated. Moreover, lipoamide dehydrogenase activity, $K m$ and Vmax were within the normal range in Friedreich's cells. These data suggest that the low' activities of the PDH complex are not a primary defect in Friedreich's ataxia, but are more likely related to membrane abnormalities in Friedreich's cells.

témoins. Ces anomalies ne furent pas observées après sonication des cellules. L'activité, le $\mathrm{Km}$ et le Vmax de la lipoamide dehydrogenase furent trouvés dans les limites normales. Ces données suggèrent que les basses activités du complexe $P D H$ ne sont pas un défaut primaire dans l'ataxie de Friedreich, mais reflètent plutôt une anomalie membranaire des cellules de Friedreich.
From Instituto Neurologico "C. Besta", Milano. Italy.

Reprint requests for the complete supplement on Friedreich's Ataxia (phase three) to: Dr. André Barbeau, Clinical Research Institute of Montreal, 110 Pine Avenue West, Montreal, Quebec, Canada, H2W IR7.

\section{INTRODUCTION}

The primary metabolic defect in Friedreich's ataxia (F.A.) has not been identified. However, data reported by Blass et al. (1976) suggested that the activities of the pyruvate-dehydrogenase and $\alpha-\mathrm{KGDHC}$ ) were low in glycerol-homogenates of cultured fibroblasts from these patients. Since these two enzymes complexes have a common component, $\mathrm{PDH}-\mathrm{E}_{3}$ or lipoamide-dehydrogenase (LAD), this activity was investigated by Kark and collaborators, $(1978,1979)$ and found to be abnormal in the cell homogenates of some Friedreich's patients. These authors showed that PDHC and $\alpha$ KGDHC activities in platelet preparations from patients with spinocerebellar degenerations were lower than in control platelets. These data were not confirmed by Barbeau et al. (1976), Melançon et al. (1979) and by Stumpf and Parks (1978, 1979). The latter authors reported normal activities of PDH, $\alpha-\mathrm{KGDH}$ and LAD in sonicated fibroblasts cultured from Friedreich's patients: at variance with the data of Rodriguez-Budelli et al., (1978) the kinetics of $L A D$ was comparable in the controls' and the patients' cells. Moreover, Stumpf and Parks (1979) showed that oxidation rates by whole cell suspensions of many substrates, including pyruvate and palmitate, from F.A. patients tallied with the rates for control cells.

In our group of F.A. patients, diagnosed according to strict clinical criteria (see D'Angelo et al. this issue), we measured the oxidation rates of pyruvate and palmitate in whole cell suspensions in optimized conditions, as previous experiments in our laboratory had shown that in trypsinsuspended cells, cofactors necessary for maximal oxidation rates of these 
substrates were lacking. Given the discrepancies between the results of Kark et al. (1979) and Blass et al. (1976) and those of Stumpf and Parks (1979) concerning the PDH activity in F.A. cells, we measured the activities of PDHC and $\alpha-\mathrm{KGDHC}$ and LAD by different methods of cell disruption in order to establish whether the contradictory results were the outcome of different methods for solubilizing the PDH and $\alpha-\mathrm{KGDH}$ complexes. Because of the putative role of carnitine-acetyl-transferase (CAT) in the control of pyruvate oxidation (Di Donato et al., 1979) this activity was determined in cultured cells, together with the activity of NADPH dependent glutamate-dehydrogenase $(\mathrm{GDH})$ an enzyme found abnormal in cerebellar degeneration of the olivopontocerebellar type (Plaitakis et al., 1979).

\section{MATERIALS AND METHODS}

Cultures of human fibroblasts from 26 normal and diseased controls (10 normal, 2 neuronal-ceroid-lipofucsinosis, 2 acid maltase deficiency, 2 acid maltase deficiency heterozygotes, 2 metachromatic leukodystrophy, 2 metachromatic leukodystrophy heterozygotes, I polymyositis, 1 mucolipidosis III, 2 Tay-Sachs disease, 2 Tay-Sachs heterozygotes and 2 undiagnosed progressive encephalopathies), 9 ataxic patients not affected by F.A. (4 olivopontocerebellar atrophy, $1 \mathrm{Holmes}$ cerebellar degeneration, 2 transient ataxias with normal PDH activity, $1 \alpha$ neuraminidase deficiency, 1 dominant CMT disease) and 11 patients with F.A. (patients 1 to 9 and 12-13 of table 1 of our previous paper), were grown from skin biopsies, in Eagle MEM supplemented with $10 \%$ foetal calf serum, buffered at $\mathrm{pH} 7.4$ with $\mathrm{Na}$ bicarbonate in $75 \mathrm{~cm}^{2}$ Falcon Flasks as previously described (Di Donato et al., 1977). Fibroblasts, subcultured 5 to 15 times, were harvested at $10 \mathrm{~min}$ incubation at $37^{\circ}$ with $0.25 \%$ trypsin in Tris-buffered saline (TBS) solution, containing $1.0 \mathrm{mM}$ EDTA, pH 7.4 . Cells were pelletted by centrifugation for $5 \mathrm{~min}$ at $2600 \mathrm{rpm}$ and washed twice with TBS. Pyruvate $1{ }^{14} \mathrm{C}$ and pyruvate $2-{ }^{14} \mathrm{C}$ oxidations were measured in TBS suspended cells in $20 \mathrm{ml}$ scintillation vials, stoppered with rubber caps, with a strip of paper moistened with $50 \mu \mathrm{l}$ of $1 \mathrm{M}$ Hyamine Hydroxide in methanol. Before the addition of labelled pyruvate, the cells were preincubated $15^{\prime}$ in TBS with 1.0 $\mathrm{mM}$ L-aspartate in order to maximize pyruvate oxidation. Incubations were then performed in a oscillating bath (25 strokes $/ \mathrm{min})$ at $37^{\circ} \mathrm{C}(30 \mathrm{~min}$ for pyruvate- $1-{ }^{-14} \mathrm{C}, 0.1 \mathrm{mM}$ final concentration; $60 \mathrm{~min}$ for pyruvate-2- ${ }^{-14} \mathrm{C}, 0.1$ $\mathrm{mM}$ final concentration). The radioactive $\mathrm{CO}_{2}$, formed during incubation times, and trapped by Hyamine Hydroxide was counted in $10 \mathrm{ml}$ of InstaGel (Packard) in a Tricarb scintillation counter. Blanks were obtained by killing the cells with methanol. Palmitate- $1-{ }^{14} \mathrm{C}$ oxidation was measured by the same method, except that incubation mixtures contained $0.1 \mathrm{mM}$ albumin-bound palmitate- $1-14 \mathrm{C}$ (albumin/palmitate ratio 0.14 ) and that cells were preincubated 15 minutes with $0.5 \mathrm{mM}$ L-carnitine before adding palmitate in order to maximize palmitate oxidation. PDHC and $\alpha-\mathrm{KGDHC}$ were measured in cell homogenates by the current radiochemical methods (Blass et al., 1976) while LAD activity was measured by the current spectrophotometric method (Di Donato et al., 1979; Stumpf and Parks, 1978): kinetics of LAD versus lipoamide as substrate were evaluated. For the LAD assay the cells were sonicated (Rodriguez-Budelli and Kark, 1978; Stumpf and Parks, 1978). On the other hand, for PDHC and $\alpha$ KGDHC two different methods of cell disruption were used (i.e. homogenization in glycerol and sonication) in order to compare the effect of homogenation on the activities of the two enzymes. The activity of carnitineacetyltransferase (CAT) was measured in cells sonicated by the radiochemical method previously described (Di Donato et al., 1979). Protein was measured with the method of Lowry et al., (1951). NADPH dependent glutamate-dehydrogenase was measured in fibroblast sonicated by the method of Schmidt (1974).

\section{RESULTS}

Preliminary experiments performed in our laboratory showed that a) suspensions of cultured fibroblasts from F.A. strains oxidized pyruvate-1${ }^{14} \mathrm{C}$, pyruvate-2- ${ }^{14} \mathrm{C}$ and palmitate-1${ }^{14} \mathrm{C}$ at the same rates as control strains; b) preincubation of normal cells with 1 mM 1-aspartate increased pyruvate oxidation with both pyruvate- $1-14 \mathrm{C}$ and pyruvate-2- $-14 \mathrm{C}$ (mean increase in pyruvate- $1-14 \mathrm{C}$ oxidation was $146 \pm$ $24 \% \mathrm{SD}$; for pyruvate-2-14 $\mathrm{C}$ it was $124 \pm$ $15 \%$ in 20 normal human strains); c) preincubation of cells with $0.5 \mathrm{mM} \mathrm{1-}$ carnitine palmitate $-1-{ }^{14} \mathrm{C}$ oxidation (means increase $196 \pm 49$ S.D. in 18 human strains). Oxidation rates for pyruvate and palmitate in F.A. and controls' cells in the presence of these cofactors are shown in table 1 . No difference between the oxidation rates for pyruvate and palmitate between controls and F.A. fibroblasts was evidenced: moreover, the mean in-

TABLE 1

Pyruvate and Palmitate Oxidations by Whole Cell Suspensions from Controls' and Friedreich's Fibroblasts*

\begin{tabular}{lcc}
\hline & Controls & Friedreich's \\
\hline Pyruvate $1-14 C^{* * *}$ & $380 \pm 118(12)$ & $400 \pm 139(8)$ \\
& $(222-598)$ & $(204-590)$ \\
Pyruvate $2{ }^{14} C^{* *}$ & $149 \pm 53(12)$ & $132 \pm 30(8)$ \\
& $(58-217)$ & $(88-163)$ \\
Palmitate $1-14 C^{* * *}$ & $30 \pm 12(18)$ & $31.0 \pm 5.0(10)$ \\
& $(16.5-52.3)$ & $(21.9-41.0)$ \\
\hline
\end{tabular}

\footnotetext{
*Values are expressed as mean picomoles $\mathrm{CO}_{2}{ }^{-14} \mathrm{C}$ formed $/ \mathrm{min} / \mathrm{mg}$ cell protein $\pm \mathrm{SD}$

**Preincubated with $1.0 \mathrm{mM} \mathrm{L}$-aspartate

***Preincubated with $0.5 \mathrm{mM}$ L-carnitine

The range of activity and the number of cell lines analyzed are indicated in brackets.
} 
crease in oxidation rates for pyruvate and palmitate due to L-aspartate and L-carnitine were comparable in controls and in F.A. patients (data not shown). The activities of PDHC and $\alpha-\mathrm{KGDHC}$ in controls, ataxic and F.A. patients are given in table 2 . The activities of PDHC and $\alpha$-KGDHC measured in glycerol-homogenates, did not significantly differ in controls and ataxic patients' whereas PDHC was significantly lower in the group of F.A. patients than in the controls $(\mathrm{P}<$ $0.001)$ and ataxic patients $(P<0.02)$. $\alpha-\mathrm{KGDH}$ activity was lower in F.A. than in controls' cells but the difference was not statistically significant ( $P$ $<0.05$ ). From table 2, however, it is clear that when PDHC and $\alpha$ $\mathrm{KGDHC}$ were measured in sonicated

TABLE 2

Activity of $P D H C$ and $\alpha-K G D H C$ in Cultured Fibroblasts from Controls Ataxic and Friedreich's Patients

Enzymes in

Glycerol

Homogenates

Control

Ataxic

F.A.

PDHC*

$569 \pm 115(20)$

(385 - 764)

$544 \pm 130(9)$

$(420-819)$

$404 \pm 109(11)$

$667 \pm 173(18)$

$651 \pm 152(9)$

(322 - 624)

$\alpha-\mathrm{KGDHC}^{*}$

$(389-1168)$

$(474-965)$

$521 \pm 227(9)$

(313-926)

Enzymes in

Cell Sonicates

$\begin{array}{lccc}\text { PDHC* }^{*} & 216 \pm 36 & \text { ND } & 248 \pm 80(6) \\ & (73-323) & & (121-423) \\ \alpha \text {-KGDHC* } & 357 \pm 36(6) & \text { ND } & 367 \pm 60(6) \\ & (147-535) & & (177-496)\end{array}$

*Activities are expressed as mean picomoles $/ \mathrm{min} / \mathrm{mg}$ cell protein $\pm \mathrm{S}$. D

$* * P<0.001$ versus controls and $P<0.02$ versus ataxic.

ND $=$ Not determined

Each value for controls and patients is the mean of two duplicate determinations.

The range of activity and the number of cell strains are indicated in brackets.

TABLE 3

Activities* of Lipoamide Dehydrogenase, Carnitine - Acetyl Transferase and Glutamate Dehydrogenase in Cultured Cells from Controls and F.A. Patients

\begin{tabular}{lcc}
\hline & Controls & F.A. \\
\hline LAD & $77 \pm 19(15)$ & $66 \pm 9(5)$ \\
& $(44-116)$ & $(57-77)$ \\
LAD km (mM lipoamide) & $1.80 \pm 0.19(15)$ & $1.84 \pm 0.47(7)$ \\
& $(1.4-2.6)$ & $(1.3-2.6)$ \\
LAD Vmax & $102 \pm 38(13)$ & $94 \pm 10(7)$ \\
& $(61-208)$ & $(83-107)$ \\
CAT & $0.33 \pm 0.03(16)$ & $0.30 \pm 0.05(6)$ \\
& $(0.25-0.40)$ & $(0.25-0.37)$ \\
GDH & $65.4 \pm 8.7(10)$ & $62.6 \pm 11.0(7)$ \\
& $(53.3-82.5)$ & $(46.1-83.6)$ \\
\hline
\end{tabular}

-Activities for the 3 enzymes are expressed as mean nanomoles $/ \mathrm{min} / \mathrm{mg}$ cell protein $\pm S$.D. each value for controls and F.A. cells in the mean of two duplicate determinations. cells, the activities of both enzyme complexes were lower than in glycerol homogenates and no statistically significant difference could be found between F.A. patient and controls. Moreover, specific activity, $\mathrm{Km}$ with lipoamide as substrate and $V \max$ of LAD did not significantly differ in controls and F.A. cells (table 3). No differences between the activities of CAT and GDH in F.A. and control cells were observed. NADPH-dependent GDH activity however, was significantly lower, than in controls, in the cultured cells from 5 patients with olivopontocerebellar atrophy (data not shown).

\section{COMMENT}

The results of preliminary experiments in our laboratory demonstrated that suspensions of cultured cells from F.A. patients oxidized pyruvate and palmitate at the same rate as controls. As cell suspensions, in the absence of added L-aspartate and L-carnitine, oxidized pyruvate and palmitate at a low rate, we measured these activities in the presence of adequate a mounts of these cofactors: again no difference in the oxidation rates of pyruvate and palmitate could be detected between F.A. and controls cells (table 1). Therefore, our data in whole cells suspensions, obtained using both pyruvate- $1-{ }^{14} \mathrm{C}$ and pyruvate-2- ${ }^{14} \mathrm{C}$, did not suggest defects in pyruvate oxidations in cultured F.A. cells, in agreement with the data of Barbeau et al., (1976) and Stumpf and Parks (1978). The use of both substrates ruled out defects of pyruvate decarboxylation and defects of pyruvate-derived acetyl-CoA utilization in the Krebs cycle. However when the activity of the PDH complex was measured by direct enzyme assay by the glycerol-homogenate method of Blass et al. (1976) a significant reduction of the PDHC activity was observed in F.A. cells versus control cells and versus ataxic non-Friedreich patients, $(\mathrm{P}<0.001$ and $\mathrm{P}<0.02$ respectively). These data are in agreement with the data reported by Blass and coworkers (1976) and differ from those reported by Stumpf and Parks (1978): the activity of $\alpha-\mathrm{KGDHC}$ was not statistically different in F.A. cells 
from that of the controls $(P<0.05)$ and ataxic patients', in our patients as well as those reported by Blass et al., (1976).

However, when sonicated cells were used to measure PDHC and $\alpha$ $\mathrm{KGDHC}$, as in the assay suggested by Stumpf and Parks, 1978, the activities of both the controls and the Friedreich'sf cells were lower than those obtained in glycerol-homogenates and no statistically significant difference could be found between Friedreich's patients and controls (Table 2), in agreement with Stumpf and Parks (1978). Therefore, the discrepancies between the data reported by the authors on the PDHC activity could be tentatively attributed to differences in the assay methods. Our data in table 3 show that the low activity of the PDHC observed in F.A. glycerolhomogenates was not a consequence of the low activity of the third component of the PDH complex. LAD specific activity in F.A. cells was normal as well as its $\mathrm{Km}$ (with lipoamide and substrate) and Vmax. Therefore, low activity in F.A. cells of the PDH complex was not correlated to: a) abnormalities of pyruvate oxidation by whole cells as the oxidations rates of both pyruvate- $1-{ }^{14} \mathrm{C}$ and pyruvate- $2-{ }^{14} \mathrm{C}$ were normal in F.A. fibroblasts in the presence and in the absence of L-aspartate; b) abnormalities of the lipoamide dehydrogenase. Moreover, low activities of the PDH complex were found in Friedreich's fibroblasts glycerol-homogenates but not in sonicated cells (table 2). These findings suggest that the low activity of the PDH complex is not a primary defect in F.A. but rather that it may perhaps be related to a) subtle abnormalities of the enzyme complex structure expressed in vitro only when conservative homogenization methods are used; b) abnormal membrane composition of the F.A. cells, as recently suggested by Barbeau (1979) resulting in different sensitivities of the cells to the disruption procedures. Work is in progress to test the latter hypothesis. The fact that CAT and GDH activities, found abnormal in some ataxic patients (Di Donato et al., 1979; Plaitakis et al., 1979) were in the normal range (table 3) in F.A. cells, suggested that these abnormalities are restricted to ataxic conditions other than F.A., namely olivopontocerebellar atrophy for GDH (Plaitakis et al., 1979). The determination of these enzymes in cultured cells, if proven reliable and significant in clinically defined diseases, may be a useful tool for discriminating ataxic phenotypes close to F.A. from the Friedreich patients.

\section{EDITOR'S NOTE}

The above paper is the same text which has been accepted for publication in the Italian Journal of Neurological Sciences (September, 1980) and is reproduced here with the express permission of the IJNS editor and the authors, because of its pertinence to the Quebec Cooperative Study on Friedreich's Ataxia and in acknowledgement of international cooperation on this important subject.

\section{REFERENCES}

BARBEAU, A., BUTTERWORTH, R.F. NGO, T., BRETON, G., MELANÇON, S., SHAPCOTT, D., GEOFFROY, G. and LEMIEUX, B. (1976). Pyruvate metabolism in Friedreich's ataxia. Can. J. Neurol. Sci., 3: 379-388

BARBEAU, A. (1979). Friedreich's ataxia: an overview. Can. J. Neurol. Sci., 6: 311-319.

BLASS, J.P., KARK, R.A.P. and MEMON, R.K. (1976). Low activities of the pyruvatedehydrogenase and oxoglutarate dehydrogenase complexes in five patients with Friedreich's ataxia. New Engl. J. Med., 295: 62-67.
D'ANGElo, A., DI DONATO. S., CRENNA. G., NEGRI S., BEULCHE, F., UZIEL, G. and BOERI, R. (1980). Friedreich ataxia I. Clinical, neurophysiological and biochemical studies in vivo. This issue.

DI DONATO, S., WIESMANN, U.N. and HERSCHKOWITZ, N.N. (1977). Membrane adsorption and internalization of $\left({ }^{14} \mathrm{C}\right)$ chloroquine by cultured human fibroblasts. Biochemical Pharmacol., 26: 7-10.

DI DONATO, S., RIMOLDI, M., MOISE, A., BERTAGNOLIO, B. and UZIEL, G. (1979). Fatal ataxic encephalopathy and carnitine acetyltranspherase deficiency: a functional defect of pyruvate oxidation? Neurology, 29: 1578-1583.

KARK, R.A.P. and RODRIGUEZ-BUDELLI, M. (1979). Pyruvate-dehydrogenase deficiency in spinocerebellar degeneration. Neurology, 29: 126-131.

LOWRY, O.H., ROSENBROUGH, N.J., FERR, A.L. and RANDELL, R.J. (1951). Protein measurement with the Folin-phenol reagent. J. Biol. Chem., 193: 265-268.

MELANÇON, S.B., POITIER, M., DALLAIRE, L., ROLLIN, R., FONTAINE, G. and GRENIER, B. (1979). Pyruvate-dehydrogenase, lipoamide-dehydrogenase and citrate-synthase activity in fibroblasts from patients with Friedreich's and CharlevoixSaguenay ataxias. Can. J. Neurol., Sci., 6: 241-242.

PLAITAKIS, A., NICKLES, W.J. and DESNICH, R.S. (1979). Glutamate-dehydrogenase deficiency in 3 patients with spinocerebellar ataxia: a new enzymatic defect? Annals Neurology, 6: 148 (abs)

RODRIGUEZ-BUDELLI, $M$. and KARK, R.A.P. (1978). Kinetic evidence for a structural abnormality of lipoamide-dehydrogenase in two patients with Friedreich's ataxia. Neurology, 28: 1283-1286.

SCHMIDT, E. (1974). Glutarate-dehydrogenase in: Bergmeyer H.U. Methods in Enzymatic Analysis Academic Press, New York, 2nd Edition, pp 650-656.

STUMPF, D.A. and PARKS, J.K. (1978), Friedreich's ataxia. I. Normal pyruvatedehydrogenase complex activity in platelets. Annals Neurology, 4: 366-368.

STUMPF, D.A. and PARKS, J.K. (1979). Friedreich's ataxia. II. Normal kinetics of lipoamide-dehydrogenase. Neurology, 29: 820-826. 